\title{
Clinical approaches to cultural diversity in mental health care and specificities of French transcultural consultations: A narrative review.
}

LAURA CARBALLEIRA CARRERA ( $\square$ laura.carballeira@gmail.com )

Hopital Cochin https://orcid.org/0000-0002-1572-5616

Sarah Lévesque-Daniel

Universite de Montreal

Rahmeth Radjack

Hopital Cochin

Marie Rose Moro

Hopital Cochin

Jonathan Lachal

Hopital Cochin

Research article

Keywords: Transcultural psychiatry, migrant families, mental healthcare, cultural diversity

Posted Date: October 31st, 2019

DOI: https://doi.org/10.21203/rs.2.12762/v2

License: (c) (i) This work is licensed under a Creative Commons Attribution 4.0 International License.

Read Full License 


\section{Abstract}

Background: Cultural context substantially affects the experience and clinical expression of psychiatric diseases, while cultural factors limit both access to and effectiveness of care, especially for migrant families requiring specific types of services. In France, Transcultural Psychotherapy is an original method conceived for therapy for immigrant families facing issues that cannot be solved in standard psychotherapy. We reviewed the international literature on child and adult mental health services to compare the different models of care and uncover the specificities of the French model. Methods: Systematic electronic search of databases (PubMed and PsycINFO), manual search of archives of journals dealing with transcultural psychiatry, and consultations with international experts, to identify all papers describing clinical models devoted to mental health care for migrants, published between January 1990 and October 2018. Narrative synthesis of the included articles. Results: The study included 28 papers. The specificities of mental health services for migrant families are linked to the host country's migration patterns and citizenship model. In English-speaking countries, specialized services for ethnic minorities offer ethnic matching of the therapist and patient. In Canada, indirect transcultural consultation services have existed since the late 1990s. Australia emphasizes the networking of consultation services and professional training in cultural competence, while the Nordic countries (Sweden, Finland, Norway, and Denmark) focus management on trauma. In France, psychotherapy services, with flexible numbers of therapists involved according to the situation, have existed since 1990. Discussion: Most initiatives place emphasis on training and supervision, in an indirect approach not specifically focused on the patient, or offer cultural matching of patient and therapist. The French transcultural approach, on the contrary, makes the family's culture and its cultural diversity an integral part of the therapy process. Although this approach appears clinically effective, constraints linked to the size of the therapist group limit its generalization to all situations and impose the need for alternative forms of care.

\section{Background}

Julian Tudor Hart set forth his famous Inverse Care Law in the Lancet (1971) (1): "The availability of good medical care tends to vary inversely with the need for it in the population served." That is, the people who need medical care most receive the least, while its availability is concentrated in the population groups that need it least. Migrants and ethnic minorities are the casualties of this systemic inequality in access to the healthcare system, especially to mental health facilities. Reports from the World Health Organization (2) and humanitarian groups such as Doctors of the World (3) reveal that the resources dedicated to mental health remain inadequate, are distributed unequally, and used inefficiently. These organizations therefore seek to promote the development of public policies to reverse this situation indisputably needed in this ever more globalized world, where migrants currently account for hundreds of millions of the world's population (4).

At the macro level, this population faces problems including a lack of health insurance coverage, lack of knowledge of the healthcare system, and linguistic barriers. At a micro level, its members run up against 
the lack of understanding, prejudices, and negative attitudes of many professionals (5). A therapist, for example, may be less interested in and devote less effort to an intervention with a patient perceived as not cooperating or as having a different system of values and with whom the therapist finds it harder to identify culturally. This affects the quality of the intervention, reproducing the Inverse Care Law (6).

This inequality in access to care has consequences at several levels. On the one hand, migrant families and ethnic minorities underutilize the primary healthcare system, at the same time as they overuse emergency departments. On the other hand, these issues can impede the professionals' understanding of the particular psychopathology and can lead to differences in the prescription of drugs, decisions about hospitalization, availability of psychotherapy, and course under treatment $(7,8)$.

Added to that are pre- and post-migration factors that act as social determinants of mental health: exposure to violence and traumatic migration experiences, the process of acculturation, situations of loss and mourning, adverse socioeconomic conditions, conflicts due to cultural differences, discrimination, and social isolation $(3,8-10)$.

Finally, it is appropriate to note the major influence of cultural factors on the ways that diseases and their treatments are conceptualized. In every culture, the manner in which symptoms are experienced and interpreted is part of its systems of meaning, and these meanings will model the ways people in those cultures become sick, or cope with feelings of unease, or seek help (11).

There are two positions about how to work with the cultural diversity of families in the organization of health care. The first expects migrant patients to adapt to conventional care, by normalizing or ignoring the differences. The second position recognizes and seeks to remedy these differences by the development of culturally sensitive approaches and clinical practices. Unfortunately, culture is often mentioned only when there are misunderstandings or at least difficulties in mutual comprehension between the professional and the patient or lack of adherence to treatment. Culture then designates a thing that belongs only to the patient and that represents an obstacle to communication and cooperation (8).

Healthcare systems can adapt in several ways: using interpreters and cultural mediators, training professionals in cultural competence (Table 1) and supervision, making innovations in the therapeutic framework of general mental health services, and developing specialized clinics for ethnic minorities (8,10,12-19). In France, a complete psychotherapeutic method was conceived in the 1980s by T. Nathan and then expanded by MR Moro (one of the authors) for the management of migrant families facing issues that cannot be solved in standard psychotherapy: Transcultural Psychotherapy (TPT). As therapists applying this method, we have reflected at length on the French model, its specificities, and its construction inside the French sociocultural context. To answer this question, we propose to conduct a narrative and international review of ways of providing psychiatric healthcare services that provide care for adults or children that takes cultural elements into account. Our aim is to compare the different models of care in order to uncover the specificities of the French model. 


\section{Methods}

This is a narrative review of the international literature on clinical approaches to cultural diversity in mental health care.

We used three different strategies for the literature search.

First, on October 1, 2018, we conducted a systematic search for articles identified in the PubMed and PsycINFO databases in response to the Boolean queries in Table 2.

After duplicates were removed, 592 titles and abstracts were screened by two researchers (LCC \& JL). The inclusion/non-inclusion criteria were the following:

- Peer reviewed journal articles

- Dealing specifically with clinical models for handling cultural diversity in psychiatric treatment

- Describing the modalities of care

- Published between January 1, 1990, and October 1, 2018

- In English, French, or Spanish.

Thirty-five full texts were retrieved.

Second, we asked within our international network of transcultural therapists (and researchers) for references to provide any journal article that met these inclusion criteria.

Finally, the research was completed by an analysis of the abstracts of the two principal journals in the national and international transcultural field: L'autre (French) and Transcultural Psychiatry (English).

These methods identified an additional 13 full-text papers.

After full-text screening, 28 papers were finally included in the review.

\section{Quality appraisal}

All the papers included were conceptual articles, and we found no existing checklists by which we could systematically assess their quality. To improve the rigor of our review, we created a simple tool to assess the quality of each paper, shown in Table 3. After the research group constructed the appraisal tool, two researchers (LCC and JL) independently evaluated each paper and the working group reached a consensus about it.

\section{Analysis}

The articles were read by three authors (LCC, JL, and MRM), and summarized by the first author. The results and their presentation were then discussed during research group meetings. To synthesize them, we looked for similarities between the care models described in the different papers and organized the 
results inductively. They nonetheless reflect, as previously described in the literature (20), the association of countries' histories, patterns of migration, citizenship models, and particularities in the development of mental health services for immigrant populations. The French model is presented in a second part of the results and is then discussed in relation to the different models in the discussion.

\section{Results}

This review includes 29 articles. Table 4 presents the principal characteristics of the articles, and Table 5 the principal characteristics of the services and care that the articles describe. The results of the critical appraisal are reported in Table 3. The quality of the articles was globally good, except for the criterion concerning the description of the international context of immigration policies. No article was excluded solely on the basis of inadequate quality.

The adaptation of mental health care to a context of cultural diversity began in English-speaking countries in the 1970s and in France in the 1980s $(12,14)$.

\section{Different types of services developed across the world}

In this first part, we sketch the different international models described in the literature. As stated above, these models have been regrouped according to their similarities and they reflect the countries' histories, patterns of migration, and citizenship models (20).

First, we find countries such as the United Kingdom and France, which have had substantial immigration from their former colonies. These migrant populations very often faced racism and discrimination on their arrival.

In England, transcultural psychiatry began to develop at the end of the 1970s, with the creation of specialized services for ethnic minorities. Later, professionals were introduced to concepts such as cultural sensitivity, antiracist practices, and misdiagnosis (diagnostic errors due to the failure to take cultural factors into account). Multicultural and multidisciplinary advisory teams appeared, and professionals of varied cultural origins were recruited (12). More recently, the United Kingdom has developed an innovative model: the Cultural Consultation Service (CCS). This is an adaptation of the model developed at McGill University in Canada (and described more fully below), which uses an ethnographic methodology and is based on medical-anthropological knowledge. These departments aim to improve the evaluation, treatment, and outcome of immigrant families. They also seek to act on the structural determinants of inequality in access to mental health care and increase the cultural competence of professionals $(17,18)$. Various practices are therefore recommended without any general consensus around a single model (12).

Some countries, such as the United States, Canada, and Australia, whose populations were shaped by successive waves of migrants, have a multicultural citizenship model. This model promotes the existence 
of multiple cultural communities within the society. These countries thus tend to recognize cultural diversity and its stakes for health in general. There are also ethnospecific clinics (20).

The United States is a country that was built largely through immigration, but has also been deeply marked by its history of slavery and racism. Despite the existence of policies promoting assimilation, migration flows have led to the preservation of different cultural communities. The development of ethnospecific clinics is a response to this diversity. In these clinics, the professionals know the language and the culture of the community they serve $(20,21)$. Ethnic matching of therapists and patients is also facilitated in general medical care $(8,22)$. Moreover, it is recommended that components of cultural competence be incorporated into any mental health program covering cultural minorities $(22,23)$.

The United States is also where ethnopsychiatry and ethnopsychoanalysis were born, after World War II, at the Menninger Clinic (in Kansas until 2002, when it moved to Texas), which used anthropology and clinical practice complementarily and strongly influenced the principal French model (24).

In Canada, cultural identity is considered fairly positively, and the concept of "reasonable accommodation" is relatively widespread. The law encourages pluralism and diversity to preserve the language and culture of ethnic minority groups and to combat racism (20). Cultural psychiatry has attempted to meet the challenges presented by the diversity of the population in general healthcare facilities, beyond the development of ethnospecific services in some cities. At the beginning of the 1990s, combining the Canadian concepts of "multiculturalisme de convivence" (multiculturalism of living together, as opposed to that of dominance) with French ethnopsychoanalytic traditions, several plans for transcultural teams took form in the Montréal region $(8,25,26)$. Clinical interventions with multi-ethnic populations and the Aboriginals are included, as well as a specific Transcultural Child Psychiatry Team (27-29), In 1999, to cope with the limitations of this system, the Cultural Consultation Service (CCS) of McGill University was created. It used a consultation-liaison model, which integrates the medicalanthropological approach and Western mental health care. Families are referred by a professional who considers that cultural factors are compromising the evaluation, treatment, or therapeutic relationship. The CCS, with the aid of interpreters and cultural mediators, assembles the information necessary to understand the patients' narratives. The team then researches and drafts a cultural formulation (Table 1), which is submitted to the referring professional, accompanied by treatment guidelines and possible management strategies $(8,30)$.

In Australia, various services have been developed to meet the needs of ethnic minorities and Indigenous communities. The choice for the Indigenous communities was to give them the control in the development and management of care services. Efforts for migrant families have primarily concentrated on language barriers and cultural competence training for professionals $(20,31)$. Accordingly, all states and territories in Australia have transcultural mental health resources, funded by the public healthcare system. They make up the Australian Transcultural Mental Health Network, whose function is to support mental health care nationwide, through research, professional training, and innovation in services. Its objective is to improve the accessibility, quality, and cultural appropriateness of mental health care for 
migrants. Specific innovations include the creation of jobs such as consultant in ethnic mental health and the recruitment of bilingual staff $(16,19,32)$. Moreover, specialized services have been developed for the treatment of victims of torture and trauma to help refugees $(33,34)$.

In New Zealand, cultural differences are addressed through Community and Liaison Services, with access to 'cultural advisers' from the indigenous community (35).

Countries that have not traditionally received large populations of migrants are also now attempting to respond to cultural diversity to provide greater social justice and appropriate care for all patients. In particular, the Nordic countries, which have been culturally homogeneous until recently (except for several indigenous minorities) have experienced an increase in the diversity of their populations. In Sweden, Finland, Norway, and Denmark, special focus has been placed on developing services to treat the sequelae of violence and trauma as well as on training in cultural competence in general healthcare facilities. Mental health services specific for indigenous populations have also been set up $(5,36-38)$.

In other European countries, isolated initiatives have been launched to respond to the increase in cultural diversity. Nonetheless no government policies have sought to improve the access of migrant families to mental health care. Italy, Germany, and Spain have set up teams aimed at providing transcultural training for mental health professionals $(7,15,39,40)$. Italy has several transcultural care teams in departments of psychiatry and child psychiatry; not only do they offer consultation-liaison services, but they can conduct psychosocial and psychotherapeutic interventions in the most complex cases $(7,15)$. In particular, Italy has developed cultural mediators, as in Milan (Crinali) (41). Germany and the Netherlands are trying to guarantee greater cultural openness in public mental health facilities $(5,42)$, while in Belgium this initiative depends more on non-profit organizations (9).

\section{The French model: transcultural psychotherapy services, with flexible numbers of therapists involved according to the situation}

The French citizenship model tends to minimize the importance of cultural differences in individuals in favor of adherence to the shared values of the Republic. Traditionally, the multiculturalism established in France is one that might be called a multiculturalism "of dominance", in which cultural identity can be expressed in the private sphere but is not recognized or valued in the public sphere. There is a widely shared fear of migrant communities. For the sake of integration, homogenization of these differences is expected in the public space $(25,26)$. Therefore, health care in France is traditionally considered to be addressed to everyone, with no specificity linked to their cultural origins and without any recognition of the obstacles that might prevent patients from access to these services, which are theoretically available to all.

Nonetheless, French psychiatrists and psychologists who see migrant patients must deal with the limitations of this concept of care. In the 1980s, the first foundations of transcultural psychiatry were laid in France, based on the ethnopsychoanalytic theories developed by Georges Devereux (43). According to Devereux, the basic mechanisms of mental functioning are universal, but the processes of an individual's 
socialization in their culture of origin must be understood to be able to access this universal dimension, since these cultural processes generate diverse and varied clinical events $(10,14)$. From this paradigm, Tobie Nathan at the Avicenne Public Hospital created an innovative psychotherapeutic framework intended for migrant families: the ethnopsychiatry group. Marie Rose Moro, who became director of the program in 1989, modified some elements to adapt it to the children of migrants (the second generation). She insists on the importance of the process of cultural métissage (hybridization) and of decentering (Table 1) (14). A group of transcultural therapists is a central element of this flexible service offered to families, and its most original aspect. We will therefore analyze it now, noting that it does not summarize the model, which can also work in small groups or on an individual basis (with or without an interpreter).

This group-based model of transcultural service shares the factors common to all psychotherapy, such as the construction of a narrative, the establishment of a therapeutic relationship, and a variety of specific theoretical and methodological factors (44).

\section{Organization of transcultural therapy}

Transcultural psychotherapy applies a therapy technique based on two complementary interpretations of symptoms rather than a simultaneous reading. Accordingly, anthropological and clinical psychoanalytic approaches are used. The clinical approaches rest on elements from psychoanalytic parent-children therapy, narrative therapy, and systemic and psychoanalytic family therapy, combined with techniques of cultural mediation (14).

Most often, referrals for transcultural management arise during the treatment of children, when medical, social, educational, or other institutions consider that second-line treatment is needed after the failure of standard management. The indication is stated in terms of the complexity of the situation and of the clinical problem, when the team referring the patient considers a cultural clinical approach necessary. In some cases, these referring teams can be seen in an indirect consultation, that is, without the family, to analyze the interventions and help adapt the care strategies $(10,44)$.

The first consultations are intended to construct the alliance and the treatment plan with the family. Once the plan is constructed, the usual follow-up is then organized in sufficiently long sessions (around 90 minutes), scheduled every 6-8 weeks.

Patients are invited to bring their families to these consultations. They are received by a group composed of several therapists of diverse cultural origins and an interpreter-cultural mediator of the same culture as the family, who can interpret successively in both directions (patient-therapist or therapist-patient). At least one professional from the referring team, who is managing and knows the patient, is also invited.

The group is multicultural and multilingual. It is directed by a principal therapist and relies on the trained co-therapists. For the management of children, one of the co-therapists becomes the auxiliary cotherapist for the child, by sitting down to play with him or her, in an area set up for this in the center of the group, with a table, crayons, and games to play. The group represents and embodies otherness and 
makes it possible to transform this otherness into a therapeutic lever. It thus serves as a support for psychological construction (45). The framework of the group functions as a transitional space in the sense used by Winnicott: a space for listening and receiving, enabling patients to talk about their cultural representations, protected from criticism and lack of understanding. The group holds the family and the child - in Winnicott's sense of "holding" (46). It becomes a transitional space: in the face of the cleavage of migration, the group is a mediator that makes it possible to integrate the culture of origin and that of the host country (14). Finally, management by a group is congruent with the collective approach to care found in traditional societies $(8,14,45,47)$.

The transcultural consultation is a flexible system, and the size of the group can be adapted to the situation. The classic large group includes around 10 co-therapists, as well as trainees. Over the years, the transcultural framework has progressively dealt with new domains, including questions of intergenerational transmission, family dynamics, and child development in the context of migration and even adoption $(14,48)$. The referrals of unaccompanied minors or patients needing specific work around psychological trauma has required some modifications in the size of the group or the function of the cotherapists (10). Experiments with smaller groups have also been proposed according to the family's cultural origin, when large groups have no particular anthropological interest (in families from Southeast Asia, for example), contrary to the families from North Africa and West Africa, who accounted for most families at the time the group system was created and for whom the group has a protective valence that facilitates expression.

The presence of the interpreter is a key parameter in transcultural work, both at the linguistic level (understanding one another) and the symbolic level (recognizing the identity and singularity of the other). The interpreter enables each family member to speak their own native tongue and to recognize its value to themselves and their children, an element that facilitates the construction of their identity $(44,49)$. It has been shown that this interpreter has a function as much for second-generation children, speaking French, as for the first generation (49).

\section{Therapeutic processes}

The objective of transcultural therapy is to promote a creative dialogue and a co-construction of personal and family narratives that lean on the representations and experiences of the patients, whether they are individuals, families, or collective groups. The principal therapist gives the floor to participants and is always the person addressed. This mode of communication, which anthropologists call indirect, enables great emotional containment. During the sessions, the co-therapists speak at the principal therapist's request to propose their hypotheses, representations, or images, relying on their own attachments, history, and culture. They may evoke myths, history, traditions, etc. These references to personal experience open the door to a dialogue about cultural complexity and the different readings possible in situations of cultural métissage (hybridization) $(10,14,44)$.

On this basis, the group enables the formulation of different conceptions of reality and of what the patient and the family are experiencing. It makes it possible to open the discussion to various - and 
sometimes divergent - daily realities. This self-disclosure by the group authorizes and supports the family members' self-narrativity. The group accompanies them in a reflexive process in which they can question themselves and transform their subjective representations. Each can thus attain a more flexible and complex self-identification and use all of their skills to find new ways of resolving their conflicts $(10,14,44,48)$.

Finally, the framework enables the emergence of narratives that are difficult to share in the framework of individual therapy. These narratives deal, for example, with migration experiences, questions about cultural métissage, and transmission, but also etiological theories about the origin of both the disease and the distress (10) (Table 1). The etiological theories can thus serve as cultural containers that make it possible to ascribe a meaning to the symptoms and to the psychological distress.

The transcultural group opposes an ethnocentric perspective and promotes transcultural encounters. The viewpoint proposed is that of the wealth and multiplicity that results from situations of métissage. It thus becomes a space where the dominant cultural discourse can be questioned, with the suspension of the psychiatric diagnosis performed from western classifications $(14,48)$.

The process of decentering is essential to allow this encounter. One of its techniques involves the analysis of cultural countertransference, defined as therapists' explicit and implicit emotional reactions to the otherness of a patient who belongs to a different culture. Therapists try to be aware of these reactions, most often during work with the group, both before and after the consultation $(10,14,45,48)$. This can also take place later, as part of group seminars where they try to describe and then analyze this cultural countertransference.

\section{Discussion}

Varied methods lead to different methods of taking cultural diversity into account in mental health treatment. Nonetheless, most of these initiatives have stressed training and supervision - the approach to care is thus indirect and does not take the patient as its object - or the cultural matching of patient and therapist. The aim of these methods is to modify the framework of care, that is, the services provided, to search for a compromise between the patient and the therapist, etc. The French transcultural approach, on the contrary, is a complete psychotherapeutic method aimed at patients rather than at the framework of care.

The models that offer matching between the therapist and patient by language or ethnicity or both present the problem that in fact language, ethnicity, and culture are not equivalent concepts. Even more, the patients have all taken part in an acculturation process that requires the métissage (mixing or blending) of ways to think about distress. In the French approach, the therapists of the group are not experts in the patient's culture, but rather in the very concept of culture and cultural attachments. The therapeutic work, which involves understanding and reflecting about the notions of cultural diversity, authorizes the family, with the group's help, to co-construct ways to think about the distress and the disease and to resolve the conflicts. These ways of thinking will in fact be métissées or hybridized, since 
migrant subjects, whether born abroad or of parents born abroad, are necessarily a hybridization of two cultures, that of their origins and that of their host country (50). The "understanding of cultural diversity" tends to predominate over "cultural competence" today (36).

The co-construction of meaning is a primary objective of the French approach. The cultural elements of the patients' attachments are not considered to be obstacles, but rather "active catalysts of the care relationship" (10). The patient's culture and various attachments are thus an integral part of the process of therapy. In this sense, the French transcultural approach is radically different from the models proposing to adapt the standard framework of care by training professionals in cultural competence $(5,13,16,19,22,23,31,51-53)$ or via integration through using interpreters or cultural mediators $(35,38,54)$.

The objective is not to adapt the framework of care to the patients' particularities, but rather to change the paradigm of care. The treatment setting is organized to enable the emergence of cultural theories that explain the symptoms, and the recourse to traditional care by the patient and family, which will be the materials to work on in therapy. The introduction of cultural rationales into therapy and the acceptance and attribution of value to non-Western representations of distress and disease become important symbolic acts, because they belong to the families and to their history, and they can appropriate them or not, according to their desire and their pathway. The therapeutic relationship is thus rebalanced, more symmetric, because the family members put into this therapeutic relationship that which they consider important and which gives meaning to what is happening to them. It is no longer the therapist alone who decides what makes sense. The patient and family members have an active position in this therapy. The group of therapists and the family co-construct the meaning. Accordingly, real therapeutic work can occur; in a situation where it was previously impossible because of the asymmetry inherent in receiving a patient of a minority culture in a facility that symbolizes the majority culture of the host country.

Along the same lines, the models of training and liaison consulting $(7,8,15,16,19,52,53)$, all involving advice to first-line therapists by transcultural experts, are limited by the adaptability of standard treatments. To the potential rigidity of the patient's psychological functioning is added the potential rigidity imposed by the type of supervision the patient's therapist receives. Transcultural psychotherapy, on the other hand, is addressed to the patient. Although the presence of the first-line therapist is encouraged to promote the patient's global therapeutic alliance, it is never compulsory, and the impossibility of working with the first-line team is never a per se limitation to the therapeutic work.

Finally, transcultural services are directed to all types of transcultural situations, unlike those aimed at specific symptoms, such as trauma $(33,34,55)$ or at a specific type of population or ethnic group $(27,31,35)$. The early data of a retrospective study underway show the clinical and cultural wealth of situations encountered (56).

\section{Strengths and limitations}

Numerous scientific publications show the clinical importance of transcultural services and therapeutic processes $(48,57-60)$. These publications reinforce the clinical observation of the effectiveness of the 
services, invented yesterday at Bobigny and Paris and deployed today in numerous French (Bobigny, Paris, Vitry-Sur-Seine, Longjumeau, Bordeaux, Toulouse, Clermont-Ferrand, Dôle, and Nantes) and European (Luxembourg, Switzerland, Italy, Spain, Portugal) mental health facilities.

Transcultural psychotherapy nonetheless presents limitations: the constraint of the group makes it more expensive than individual therapists and limit its mobility - patients must come to the center for therapy, while cultural counseling can be delivered at the patient's usual treatment site. This method is therefore not appropriate for all situations; moreover it is indicated only as second-line treatment, after standard care has failed. It must serve as a supplement to other types of action, such as the training and supervision of individual first-line therapists, transcultural mediation services in hospital departments, or still other methods adapted for specific populations - Parisian centers, for example, have set up less burdensome forms of treatment for families with international adoptions (61) and for unaccompanied minors (60).

\section{Declarations}

Ethics approval and consent to participate:

Not applicable

Consent for publication:

Not applicable

Availability of data and material:

Not applicable

Competing interests:

The authors declare that they have no competing interests.

Funding:

LCC received a grant from the Alicia Koplowitz Foundation (Spain) for a research stay in Maison de Solenn (AP-HP, Cochin Hospital Paris, France), which allowed her to conduct this study.

Authors' contributions:

All the authors participated in every step of the conception of this paper, its writing, and its final approval.

Acknowledgements: 
With thanks to Jo Ann Cahn for the translation.

Abbreviations

Not applicable

\section{References}

1. Tudor Hart J. the Inverse Care Law. Lancet. 1971;297(7696):405-12.

2. WHO. mhGAP Mental Health Gap Action Programme. Scaling up care for mental, neurological, and substance use disorders. 2008;2017.

3. Centre Primo Levi, Médecins du Monde. La souffrance psychique des exilés: Une urgence de santé publique. 2018;

4. IOM IO for M. World Migration Report 2018. International Organization for Migration; 2018.

5. Bäärnhielm S, Jávo C, Mäsko MO. Opening up mental health service delivery to cultural diversity: Current situation, development and examples from three northern european countries. Cult Psychiatry. 2013;33:40-55.

6. Carmona M. [Asociación Madrileña de Salud Mental]. (2018). Perspectivas en cuidados en salud mental. XI congreso de la AMSM [Video file] [Internet]. 2018. Available from: https://www.youtube.com/watch?v=R28-5sw6lk8

7. Tarricone I, Braca M, Atti AR, Pedrini E, Morri M, Poggi F, et al. Clinical features and pathway to care of migrants referring to the Bologna Transcultural Psychiatric Team. Int J Cult Ment Health. 2009;2(1 PG-1-15):1-15.

8. Kirmayer LJ. Cultural Consultation. Kirmayer, L.J., Guzder, J., Rousseau C, editor. Springer, New York, NY; 2014.

9. Serneels G, Villanueva O’Driscoll J, Imeraj L, Vanfraussen K, Lampo A. An Intervention Supporting the Mental Health of Children with a Refugee Background. Issues Ment Health Nurs. 2017;38(4):327-36.

10. Radjack R, Rizzi AT, Harf A, Moro MR. Actualités en psychiatrie transculturelle en France. Ann Med Psychol (Paris). 2017;175(6):561-6.

11. Groleau D, Young A, Kirmayer LJ. The McGill Illness Narrative Interview (MINI): AN Interview Schedule to Elicit Meanings and Modes of Reasoning Related to Illness Experience. Transcult Psychiatry. 2006;43(4):671-91.

12. Fernando S. Multicultural Mental Health Services: ProjectS for Minority Ethnic Communities in England. Transcult Psychiatry. 2005;42(3):420-36.

13. Ganesan S, Janzé T. Overview of Culturally-Based Mental Health Care in Vancouver. Transcult Psychiatry. 2005;42(3):478-90.

14. Sturm G, Heidenreich F, Moro M. Transcultural Clinical Work with Immigrants, Asylum Seekers and Refugees at Avicenne Hospital, France. Int J Migr Heal Soc Care. 2009;4(4):33-40. 
15. Tarricone I, Atti AR, Braca M, Pompei G, Morri M, Poggi F, et al. Migrants referring to the Bologna Transcultural Psychiatric Team: Reasons for drop-out. Int J Soc Psychiatry. 2011;57(6):627-30.

16. McDonough S, Chopra P, Tuncer C, Schumacher B, Bhat R. Enhancing cultural responsiveness: The development of a pilot transcultural secondary consultation program. Australas Psychiatry. 2013;21(5):494-8.

17. Owiti JA, Ajaz A, Ascoli M, de Jongh B, Palinski A, Bhui KS. Cultural consultation as a model for training multidisciplinary mental healthcare professionals in cultural competence skills: Preliminary results. J Psychiatr Ment Health Nurs. 2014;21(9):814-26.

18. Bhui K, Warfa N, Edonya P, McKenzie K, Bhugra D. Cultural competence in mental health care: A review of model evaluations. BMC Health Serv Res. 2007;7.

19. Santhanam-Martin R, Fraser N, Jenkins A, Tuncer C. Evaluation of cultural responsiveness using a transcultural secondary consultation model. Transcult Psychiatry. 2017;54(4):488-501.

20. Kirmayer LJ, Minas $\mathrm{H}$. The future of cultural psychiatry: An international perspective. Can $\mathrm{J}$ Psychiatry. 2000;45(5):438-46.

21. Montijo JA, Juan S, Rico P. Therapeutic relationshipts with the poor: A Puerto Rican perspective. Psychotherapy. 1985;22(2):436-40.

22. Ton H, Koike A, Hales RE, Johnson jo A, Hilty DM. A Qualitative Needs Assessment for Development of a Cultural Consultation Service. Transcult Psychiatry. 2005;42(3):491-504.

23. Siegel C, Haughland G, Reid-Rose L, Hopper K. Components of Cultural Competence in Three Mental Health Programs. Psychiatr Serv. 2011;62 (6).

24. Devereux G. Essais d'ethnopsychiatrie générale. Éditions Gallimard, editor. Paris; 1970.

25. Sironi F, de La Noë Q, Cao Huu Hai E, Fermi P, Mestre C, Abdessalem Y, et al. Quelques lieux de consultation d'ethnopsychiatrie. Carnet Psy. 1998;33:19-27.

26. Sterlin C. L'ethnopsychiatrie au Québec: bilan et perspectives d'un témoin acteur clé. Sante Ment Que. 2006;31(2):179.

27. Noël D. Mental health for the Aboriginals: a transcultural response. Ethnopsychiatrie. 2006;31 (2).

28. Measham T, Rousseau C, Nadeau L. The Development and Therapeutic Modalities of a Transcultural Child Psychiatry Service. Can Child Adolesc Psychiatr Rev. 2005;14 (3):68-72.

29. Nadeau L, Rousseau C, Séguin Y. Preliminary qualitative evaluation of a shared-care mental health programme with youths in Montréal: facing institutional and cultural uncertainty. Santé Ment en première ligne. 2009;43 (1).

30. Kirmayer LJ, Groleau D, Guzder J, Blake C, Jarvis E. Cultural Consultation: A Model of Mental Health Service for Multicultural Societies. Can J Psychiatry-Revue Can Psychiatr. 2003;48(3):145-53.

31. Doyle K, Hungerford C. Adapting Evidence-Based Interventions to Accommodate Cultural Differences: Where Does this Leave Effectiveness? Issues Ment Health Nurs. 2014;35:739-44.

32. Barrington AJ, Shakespeare-Finch J. Giving voice to service providers who work with survivors of torture and trauma. Qual Health Res. 2014;24(12):1686-99. 
33. Reid J, Silove D, Tarn R. The Development of the New South Wales Service for the Treatment and Rehabilitation of Torture and Trauma Survivors (Startts): The First Year. Aust New Zeal J Psychiatry. 1990;24(4):486-95.

34. Signorelli RG, Coello M, Momartin S. Change and Recovery: Culturally Appropriate Early Childhood Programmes with Refugee Families and Communities. Child Aust. 2015;40(3):195-204.

35. Chaplow D, Chaplow R, Winston T. Addressing cultural differences In institutions: changing health practices in New Zealand. Crim Behav Ment Heal. 1993;3:307-21.

36. Shahnavaz S, Ekblad S. Understanding the Culturally Diverse in Psychiatry Rather than Being Culturally Competent - a Preliminary Report of Swedish Psychiatric Teams' Views on Transcultural Competence. Int J Migr Heal Soc Care. 2007;3(4):14-30.

37. Ekblad S, Kastrup MC. Current research in transcultural psychiatry in the Nordic countries. Transcult Psychiatry. 2013;50(6):841-57.

38. Groen SPN, Richters A, Laban CJ, Devillé WLJM. Implementation of the Cultural Formulation through a newly developed Brief Cultural Interview: Pilot data from the Netherlands. Transcult Psychiatry. 2017;54(1):3-22.

39. Sanjuan L. Propuesta de materiales para atención en salud mental en un contexto intercultural. Rev Recer i Form en Antropol. 2007;6:1-32.

40. Bäärnhielm S, Mösko M. Cross-cultural training in mental health care - challenges and experiences from Sweden and Germany. Eur Psychiatry. 2012;27 (2):70-5.

41. http://www.crinali.org/.

42. de Jong JTVM, Van Ommeren M. Mental Health Services in a Multicultural Society: InterculturalizatioN and its Quality Surveillance. Transcult Psychiatry. 2005;42(3):437-56.

43. Devereux G. De l'angoisse à la méthode dans les sciences du comportement. Paris: Flammarion; 1967. $474 \mathrm{p}$.

44. Moro MR, De La Noë Q, Mouchenik Y. Manuel de psychiatrie transculturelle. La pensée. Grenoble, France; 2006.

45. Moro MR. Comprendre et soigner. La consultation d'Avicenne: un dispositif métissé et cosmopolite. Bobigny: Association Internationale d'EthnoPsychanalyse. 2016;

46. Winnicott DW. Playing and Reality. Penguin Bo. London; 1971.

47. Sturm G, Guerraoui Z, Bonnet S, Gouzvinski F, Raynaud JP. Adapting services to the needs of children and families with complex migration experiences: The Toulouse University Hospital's intercultural consultation. Transcult Psychiatry. 2017;54(4):445-65.

48. Sturm G, Nadig M, Moro MR. Current developments in French ethnopsychoanalysis. Transcult Psychiatry. 2011;48(3):205-27.

49. Rousseau C, Measham T, Moro MR. Working with Interpreters in Child Mental Health. Child Adolesc Ment Health. 2011;16(1):55-9. 
50. Moro MR. Parents-enfants en situation migratoire: une nouvelle clinique des métissages. In: Psychopathologie transculturelle. Elsevier Masson; 2009.

51. Bäärnhielm S, Mösko M. Cross-cultural training in mental health care - challenges and experiences from Sweden and Germany. Eur Psychiatry. 2012;27 (2):70-5.

52. Bhui KS, Owiti JA, Palinski A, Ascoli M, De Jongh B, Archer J, et al. A cultural consultation service in East London: Experiences and outcomes from implementation of an innovative service. Int Rev Psychiatry. 2015;27(1):11-22.

53. Owiti JA, Ajaz A, Ascoli M, de Jongh B, Palinski A, Bhui KS. Cultural consultation as a model for training multidisciplinary mental healthcare professionals in cultural competence skills: preliminary results: Cultural consultation model. J Psychiatr Ment Health Nurs. 2013 Dec;n/a-n/a.

54. Arafat NM. Language, culture and mental health: a study exploring the role of the transcultural mental health worker in Sheffield, UK. Int J Cult Ment Health. 2016;9(1):71-95.

55. Han M, Valencia M, Lee YSOO, Leon JDE. Development and Implementation of the Culturally Competent Program with Cambodians: The Pilot Psycho-Social-Cultural Treatment. J Ethn Cult Divers Soc Work. 2012;21:212-30.

56. Lachal J, Simon A, Hassler C, Barry C, Camara H, Massar i N, et al. An epidemiological description of 529 families treated by the French method of Transcultural Psychotherapy: A decade of experience. (unpublished). 2019;

57. Moro MR. Les soins en situation transculturelle. In: Psychopathologie transculturelle. Elsevier Masson; 2009.

58. Moro MR. Parents and infants in changing cultural context: Immigration, trauma, and risk. Infant Ment Heal J. 2003;24(3):240-64.

59. Moro MR. Parenthood in Migration: How to Face Vulnerability. Cult Med Psychiatry. 2014;38 (1):1327.

60. Woestelandt L, Touhami F, Radjack R, Moro MR LJ. Initier un suivi psychiatrique chez les jeunes isolés étrangers. Soins Psychiatr. 2017;38(313):15-8.

61. Harf A, Skandrani S, Sibeoni J, Al E. Cultural identity and internationally adopted children: qualitative approach to parental representations. PLoS One. 2015;10 (3).

\section{Tables}




\begin{tabular}{|c|c|}
\hline $\begin{array}{l}\text { Cultural } \\
\text { competence }\end{array}$ & $\begin{array}{l}\text { There are several definitions of this term in mental health care. A review of the } \\
\text { literature (18) defines this concept as the skill set that enables professionals to provide } \\
\text { culturally appropriate care. This includes consideration of differences due to language } \\
\text { and to cultural influences on the expression of distress and ways of seeking help. Other } \\
\text { aspects mentioned include respect for the patient's beliefs, as well as a disposition, } \\
\text { even a real desire, to learn about other cultures. }\end{array}$ \\
\hline $\begin{array}{l}\text { Cultural } \\
\text { formulation }\end{array}$ & $\begin{array}{l}\text { DSM-5 introduced a cultural formulation interview. This evidence-based tool is } \\
\text { composed of a series of questions that assist clinicians in making person-centered } \\
\text { cultural assessments to inform diagnosis and treatment planning. }\end{array}$ \\
\hline Decentering & $\begin{array}{l}\text { Decentering refers to the ability to distance oneself from oneself and from one's own } \\
\text { cultural point of view (48). }\end{array}$ \\
\hline Etiological theories & $\begin{array}{l}\text { The etiological theories refer to the traditional explanations for the disease found in } \\
\text { non-Western societies - imputed to nonhuman invisible beings (10). Transcultural } \\
\text { psychiatry proposes to use these traditional etiologies as a therapeutic lever in their } \\
\text { function as cultural containers. In situations of distress or disease, the subject looks to } \\
\text { "make sense of the senseless" (62) or of "misfortune" (44). The use of etiological } \\
\text { theories belonging to patients allows them to participate actively in the search for } \\
\text { meaning and for a solution to the symptoms and their various forms of distress. }\end{array}$ \\
\hline
\end{tabular}

\section{Table 1 - Definitions}

\begin{tabular}{|l|l|}
\hline & $\begin{array}{l}\text { ("cultural"[Title] OR "transcultural"[Title] OR "intercultural"[Title] OR "cross cultural" [Title]) } \\
\text { (PubMed) } \\
\text { ("cultural" [TI] OR "transcultural"[TI] OR "intercultural" [TI] OR "cross cultural" [TI]) (PsychInfo) }\end{array}$ \\
\hline AND & ("migrants" OR "ethnic minorities" OR "cultural diversity") \\
\hline AND & ("psychiatrist" OR "mental health") \\
\hline AND & ("care" OR "services" OR "treatment") \\
\hline
\end{tabular}

\section{Table 2 - Boolean queries for database searches}




\begin{tabular}{|c|c|c|c|c|c|c|}
\hline Reference & $\begin{array}{c}\text { The } \\
\text { authors' } \\
\text { affiliations } \\
\text { are clear }\end{array}$ & $\begin{array}{l}\text { The international } \\
\text { context of } \\
\text { migration and } \\
\text { mental health } \\
\text { policies is } \\
\text { adequately } \\
\text { described }\end{array}$ & $\begin{array}{l}\text { The national } \\
\text { context of } \\
\text { migration and } \\
\text { mental health } \\
\text { policies are } \\
\text { adequately } \\
\text { described }\end{array}$ & $\begin{array}{c}\text { The } \\
\text { health } \\
\text { services } \\
\text { available } \\
\text { are } \\
\text { identified }\end{array}$ & $\begin{array}{l}\text { The } \\
\text { description } \\
\text { of the } \\
\text { available } \\
\text { health } \\
\text { services is } \\
\text { adequately } \\
\text { clear }\end{array}$ & $\begin{array}{l}\text { The authors } \\
\text { discuss the } \\
\text { limitations of } \\
\text { the health } \\
\text { services } \\
\text { available }\end{array}$ \\
\hline (54) & 5 & 2 & 5 & 5 & 4 & 4 \\
\hline$(51)$ & 5 & 4 & 5 & 5 & 4 & 5 \\
\hline$(5)$ & 5 & 4 & 5 & 5 & 5 & 3 \\
\hline$(32)$ & 5 & 0 & 2 & 5 & 4 & 3 \\
\hline$(52)$ & 5 & 0 & 5 & 5 & 5 & 5 \\
\hline (35) & 5 & 5 & 1 & 5 & 5 & 5 \\
\hline (63) & 5 & 3 & 4 & 5 & 5 & 4 \\
\hline$(31)$ & 5 & 0 & 2 & 4 & 4 & 2 \\
\hline (37) & 5 & 2 & 5 & 3 & 2 & 4 \\
\hline$(12)$ & 5 & 2 & 5 & 5 & 5 & 5 \\
\hline (13) & 5 & 0 & 4 & 5 & 5 & 5 \\
\hline$(38)$ & 5 & 0 & 3 & 3 & 2 & 5 \\
\hline$(55)$ & 5 & 0 & 4 & 5 & 5 & 5 \\
\hline$(64)$ & 5 & 2 & 3 & 5 & 5 & 5 \\
\hline$(16)$ & 5 & 2 & 3 & 5 & 5 & 5 \\
\hline$(49)$ & 5 & 0 & 5 & 5 & 5 & 5 \\
\hline (29) & 5 & 0 & 5 & 5 & 5 & 5 \\
\hline$(27)$ & 5 & 0 & 5 & 5 & 5 & 5 \\
\hline$(53)$ & 5 & 5 & 4 & 5 & 5 & 5 \\
\hline (33) & 5 & 3 & 5 & 5 & 5 & 5 \\
\hline$(21)$ & 5 & 0 & 1 & 3 & 2 & 1 \\
\hline (19) & 5 & 0 & 5 & 5 & 5 & 5 \\
\hline$(9)$ & 5 & 4 & 5 & 5 & 5 & 5 \\
\hline (23) & 5 & 0 & 4 & 5 & 5 & 3 \\
\hline (34) & 5 & 0 & 2 & 5 & 5 & 4 \\
\hline (26) & 5 & 3 & 4 & 4 & 3 & 4 \\
\hline (15) & 5 & 3 & 5 & 5 & 5 & 5 \\
\hline$(7)$ & 5 & 3 & 5 & 5 & 5 & 5 \\
\hline (22) & 5 & 0 & 5 & 5 & 5 & 5 \\
\hline
\end{tabular}

Table 3 - Evaluation of the quality of the studies - graded from 0 (absent) to 5 (clear) 


\begin{tabular}{|c|c|c|c|c|c|c|}
\hline Reference & Year & Country & Aim of the study & $\begin{array}{c}\text { Type of } \\
\text { adaptation of } \\
\text { the healthcare } \\
\text { system }\end{array}$ & Main results & Main conclusions \\
\hline (54) & 2016 & UK & $\begin{array}{l}\text { It aims to explore } \\
\text { the role of the } \\
\text { "transcultural } \\
\text { mental health } \\
\text { worker" as an } \\
\text { alternative to the } \\
\text { use of interpreters }\end{array}$ & $\begin{array}{l}\text { Making } \\
\text { innovations in } \\
\text { the therapeutic } \\
\text { framework of } \\
\text { general mental } \\
\text { health services: } \\
\text { Introducing a } \\
\text { 'Transcultural } \\
\text { Mental Health } \\
\text { Worker' }\end{array}$ & $\begin{array}{l}\text { Participants found } \\
\text { working with } \\
\text { transcultural } \\
\text { mental health } \\
\text { workers either } \\
\text { more effective than } \\
\text { or as effective as } \\
\text { interpreters. }\end{array}$ & $\begin{array}{l}\text { The study } \\
\text { highlights the } \\
\text { importance of } \\
\text { providing } \\
\text { linguistically and } \\
\text { culturally } \\
\text { appropriate } \\
\text { treatment } \\
\text { modalities for } \\
\text { minority ethnic } \\
\text { patients }\end{array}$ \\
\hline (51) & 2012 & $\begin{array}{l}\text { Sweden \& } \\
\text { Germany }\end{array}$ & $\begin{array}{l}\text { To provide an } \\
\text { overview and a } \\
\text { critical } \\
\text { examination of } \\
\text { current } \\
\text { conceptualization } \\
\text { of cross-cultural } \\
\text { mental health } \\
\text { training. }\end{array}$ & $\begin{array}{l}\text { Cross-cultural } \\
\text { competence } \\
\text { training } \\
\text { programs and } \\
\text { supervision }\end{array}$ & $\begin{array}{l}\text { Description of the } \\
\text { adaptations made } \\
\text { in Sweden and } \\
\text { Germany }\end{array}$ & $\begin{array}{l}\text { The authors } \\
\text { criticize "cultural } \\
\text { competence" as it } \\
\text { is conceptualized } \\
\text { and propose } \\
\text { different ways for } \\
\text { "cross-cultural" } \\
\text { training }\end{array}$ \\
\hline (5) & 2013 & $\begin{array}{l}\text { Sweden, } \\
\text { Norway \& } \\
\text { Germany }\end{array}$ & $\begin{array}{l}\text { To examine } \\
\text { cultural diversity } \\
\text { in the countries in } \\
\text { question, discuss } \\
\text { challenges and } \\
\text { give examples of } \\
\text { current work to } \\
\text { open up mental } \\
\text { health services to } \\
\text { cultural diversity }\end{array}$ & $\begin{array}{l}\text { i) Cultural } \\
\text { competence } \\
\text { training for } \\
\text { professionals } \\
\text { and ii) } \\
\text { Developing } \\
\text { specialized } \\
\text { services for } \\
\text { ethnic } \\
\text { minorities }\end{array}$ & $\begin{array}{l}\text { In all three } \\
\text { countries, some } \\
\text { efforts have been } \\
\text { made to provide } \\
\text { culturally sensitive } \\
\text { mental health } \\
\text { services }\end{array}$ & $\begin{array}{l}\text { The development } \\
\text { of culturally- } \\
\text { sensitive care } \\
\text { requires } \\
\text { institutionalized } \\
\text { support, long- } \\
\text { term funding, } \\
\text { research, } \\
\text { guidelines and } \\
\text { training of staff }\end{array}$ \\
\hline (32) & 2014 & Australia & $\begin{array}{l}\text { To explore the } \\
\text { experience of } \\
\text { clinicians who are } \\
\text { vicariously } \\
\text { exposed to trauma, } \\
\text { because they } \\
\text { support people } \\
\text { from refugee- and } \\
\text { asylum-seeking } \\
\text { backgrounds }\end{array}$ & $\begin{array}{l}\text { Developing } \\
\text { specialized } \\
\text { clinics: Services } \\
\text { to refugees, } \\
\text { asylum seekers, } \\
\text { displaced } \\
\text { persons, or } \\
\text { migrants who } \\
\text { have } \\
\text { experienced } \\
\text { torture and } \\
\text { trauma }\end{array}$ & $\begin{array}{l}\text { The findings } \\
\text { demonstrated that } \\
\text { clinicians can be } \\
\text { positively and } \\
\text { negatively affected } \\
\text { by their work and } \\
\text { that mobilizing } \\
\text { appropriate coping } \\
\text { strategies can help } \\
\text { to minimize } \\
\text { distress }\end{array}$ & $\begin{array}{l}\text { A number of } \\
\text { challenges can } \\
\text { affect clinician } \\
\text { well-being } \\
\text { supporting } \\
\text { refugees, and } \\
\text { care must be } \\
\text { taken to ensure } \\
\text { that the risks of } \\
\text { trauma work are } \\
\text { minimized }\end{array}$ \\
\hline$(52)$ & 2015 & UK & $\begin{array}{l}\text { This paper reports } \\
\text { on a feasibility } \\
\text { study and } \\
\text { evaluation of a new }\end{array}$ & $\begin{array}{l}\text { Cultural } \\
\text { competence } \\
\text { training for } \\
\text { professionals }\end{array}$ & $\begin{array}{l}\text { The CCS model of } \\
\text { care improved } \\
\text { service-user } \\
\text { experience and }\end{array}$ & $\begin{array}{l}\text { Overall, the CCS } \\
\text { seemed } \\
\text { acceptable and } \\
\text { the }\end{array}$ \\
\hline
\end{tabular}




\begin{tabular}{|c|c|c|c|c|c|c|}
\hline & & & $\begin{array}{l}\text { type of cultural } \\
\text { consultation } \\
\text { service (CCS) }\end{array}$ & & $\begin{array}{l}\text { recovery, } \\
\text { workforce } \\
\text { development, and } \\
\text { saved costs on out- } \\
\text { patient contacts, } \\
\text { while improving } \\
\text { overall functioning } \\
\text { in the most } \\
\text { complex cases }\end{array}$ & $\begin{array}{l}\text { implementation } \\
\text { and use of the } \\
\text { service by } \\
\text { patients showed } \\
\text { feasibility for } \\
\text { future work }\end{array}$ \\
\hline (35) & 1993 & $\begin{array}{c}\text { New } \\
\text { Zealand }\end{array}$ & $\begin{array}{l}\text { This article } \\
\text { describes how } \\
\text { cultural } \\
\text { differences are } \\
\text { addressed by the } \\
\text { Regional Forensic } \\
\text { Psychiatric } \\
\text { Services of } \\
\text { Auckland and } \\
\text { Northland }\end{array}$ & $\begin{array}{l}\text { Making } \\
\text { innovations in } \\
\text { the therapeutic } \\
\text { framework of } \\
\text { general mental } \\
\text { health services: } \\
\text { Community and } \\
\text { Liaison } \\
\text { Services, with } \\
\text { access to } \\
\text { 'cultural } \\
\text { advisers' from } \\
\text { the indigenous } \\
\text { community }\end{array}$ & $\begin{array}{l}\text { They describe how } \\
\text { cultural differences } \\
\text { are addressed by } \\
\text { departments, } \\
\text { through liaison } \\
\text { with the local } \\
\text { tribes and the } \\
\text { active recruitment } \\
\text { of culturally } \\
\text { representative staff }\end{array}$ & $\begin{array}{l}\text { Efforts are being } \\
\text { made in New } \\
\text { Zealand to } \\
\text { address cultural } \\
\text { differences in } \\
\text { institutions. To } \\
\text { this end, } \\
\text { alternative } \\
\text { cultural services } \\
\text { are being } \\
\text { established by } \\
\text { tribal groups. } \\
\text { When this } \\
\text { separate provision } \\
\text { of services is not } \\
\text { possible, } \\
\text { implementation of } \\
\text { biculturalism is } \\
\text { being made to } \\
\text { provide high- } \\
\text { quality services to } \\
\text { patients. }\end{array}$ \\
\hline (63) & 2005 & Netherlands & $\begin{array}{l}\text { The purpose of this } \\
\text { article is to } \\
\text { present a model to } \\
\text { promote and assess } \\
\text { interculturalization } \\
\text { of mental } \\
\text { healthcare services }\end{array}$ & $\begin{array}{l}\text { i) Training } \\
\text { professionals in } \\
\text { "ethnocultural } \\
\text { sensitivity" and } \\
\text { ii) Making } \\
\text { innovations in } \\
\text { the therapeutic } \\
\text { framework of } \\
\text { general mental } \\
\text { health services: } \\
\text { Interpreters, } \\
\text { culture-brokers } \\
\text { and cultural } \\
\text { consultants } \\
\text { services }\end{array}$ & $\begin{array}{l}\text { The model } \\
\text { describes } \\
\text { qualitative and } \\
\text { quantitative } \\
\text { criteria and } \\
\text { indicators to be } \\
\text { applied in the } \\
\text { different contexts }\end{array}$ & $\begin{array}{l}\text { They are } \\
\text { uncomplicated } \\
\text { tools to evaluate } \\
\text { the inter- } \\
\text { culturalization } \\
\text { process of mental } \\
\text { health services }\end{array}$ \\
\hline (31) & 2014 & Australia & $\begin{array}{l}\text { This paper } \\
\text { considers the } \\
\text { processes by which } \\
\text { evidence-based }\end{array}$ & $\begin{array}{l}\text { Cultural } \\
\text { competence } \\
\text { training for } \\
\text { professionals }\end{array}$ & $\begin{array}{l}\text { They describe the } \\
\text { Aboriginal Mental } \\
\text { Health First Aid } \\
\text { course program, a }\end{array}$ & $\begin{array}{l}\text { The paper } \\
\text { concludes by } \\
\text { outlining the } \\
\text { steps mental }\end{array}$ \\
\hline
\end{tabular}




\begin{tabular}{|c|c|c|c|c|c|c|}
\hline & & & $\begin{array}{l}\text { interventions can } \\
\text { be adapted by } \\
\text { health } \\
\text { professionals in } \\
\text { any context; and } \\
\text { includes an } \\
\text { example of a } \\
\text { successful cultural } \\
\text { adaptation to an } \\
\text { evidence-based } \\
\text { intervention }\end{array}$ & & $\begin{array}{l}\text { training for } \\
\text { professionals to } \\
\text { assist people with } \\
\text { mental health } \\
\text { issues from } \\
\text { culturally diverse } \\
\text { backgrounds }\end{array}$ & $\begin{array}{l}\text { health } \\
\text { professionals can } \\
\text { take when } \\
\text { adapting } \\
\text { evidence-based } \\
\text { interventions for } \\
\text { use in their own } \\
\text { work- place } \\
\text { settings }\end{array}$ \\
\hline (37) & 2013 & $\begin{array}{c}\text { Nordic } \\
\text { Countries }\end{array}$ & $\begin{array}{l}\text { This article } \\
\text { discusses major } \\
\text { themes in recent } \\
\text { transcultural } \\
\text { psychiatric } \\
\text { research in the } \\
\text { Nordic countries } \\
\text { from: (a) } \\
\text { epidemiological } \\
\text { studies of } \\
\text { migration, (b) } \\
\text { indigenous } \\
\text { populations, and } \\
\text { (c) quality of } \\
\text { psychiatric care } \\
\text { for migrants }\end{array}$ & $\begin{array}{l}\text { Developing } \\
\text { specialized } \\
\text { clinics for } \\
\text { trauma-affected } \\
\text { refugees } \\
\text { and ethnic } \\
\text { minorities }\end{array}$ & $\begin{array}{l}\text { Varied } \\
\text { communication } \\
\text { patterns and } \\
\text { cultural and } \\
\text { linguistic } \\
\text { differences } \\
\text { complicate the } \\
\text { process of } \\
\text { diagnosing and } \\
\text { treating patients } \\
\text { from immigrant } \\
\text { backgrounds. } \\
\text { Qualitative } \\
\text { research methods } \\
\text { may be most } \\
\text { appropriate for } \\
\text { exploratory studies } \\
\text { in this emerging } \\
\text { field. }\end{array}$ & $\begin{array}{l}\text { This review } \\
\text { underlines the } \\
\text { need for } \\
\text { formalized } \\
\text { education and } \\
\text { training of clinical } \\
\text { staff }\end{array}$ \\
\hline (12) & 2005 & UK & $\begin{array}{l}\text { It describes } \\
\text { several projects } \\
\text { that have been } \\
\text { developed within } \\
\text { the NHS in } \\
\text { different parts of } \\
\text { England }\end{array}$ & $\begin{array}{l}\text { Developing } \\
\text { specialized } \\
\text { services for } \\
\text { ethnic } \\
\text { minorities }\end{array}$ & $\begin{array}{l}\text { There are a variety } \\
\text { local projects } \\
\text { incorporating good } \\
\text { practices, but } \\
\text { there is no overall } \\
\text { consensus on a } \\
\text { single good } \\
\text { practice model }\end{array}$ & $\begin{array}{l}\text { Sustainable } \\
\text { changes require a } \\
\text { national plan and } \\
\text { strategy to } \\
\text { promote } \\
\text { innovations in } \\
\text { general mental } \\
\text { health services }\end{array}$ \\
\hline (13) & 2005 & Canada & $\begin{array}{l}\text { This article is a } \\
\text { description of how } \\
\text { cross-cultural } \\
\text { services in mental } \\
\text { health have } \\
\text { evolved in } \\
\text { Vancouver }\end{array}$ & $\begin{array}{l}\text { i) Developing } \\
\text { specialized } \\
\text { services for } \\
\text { ethnic } \\
\text { minorities; ii) } \\
\text { Cultural } \\
\text { competence } \\
\text { training for } \\
\text { professionals; } \\
\text { and iii) Making } \\
\text { innovations in } \\
\text { the therapeutic }\end{array}$ & $\begin{array}{l}\text { The cross-cultural } \\
\text { mental health } \\
\text { service has } \\
\text { experienced } \\
\text { increased } \\
\text { coordination under } \\
\text { the regional health } \\
\text { services } \\
\text { administration }\end{array}$ & $\begin{array}{l}\text { Vancouver cross- } \\
\text { cultural mental } \\
\text { health system } \\
\text { provides health } \\
\text { care that is } \\
\text { accessible, } \\
\text { available and } \\
\text { acceptable to all, } \\
\text { and develops } \\
\text { health care that } \\
\text { acknowledges } \\
\text { racial and }\end{array}$ \\
\hline
\end{tabular}




\begin{tabular}{|c|c|c|c|c|c|c|}
\hline & & & & $\begin{array}{l}\text { framework of } \\
\text { general mental } \\
\text { health services: } \\
\text { Interpreter } \\
\text { Services and } \\
\text { Multicultural } \\
\text { Liaison Program }\end{array}$ & & $\begin{array}{l}\text { cultural } \\
\text { diversities }\end{array}$ \\
\hline (38) & 2017 & Netherlands & $\begin{array}{l}\text { This article } \\
\text { presents a study } \\
\text { on the feasibility, } \\
\text { acceptability, and } \\
\text { utility of the Brief } \\
\text { Cultural Interview } \\
\text { (BCI), with refugee } \\
\text { and asylum- } \\
\text { seeking patients in } \\
\text { a Dutch center for } \\
\text { transcultural } \\
\text { psychiatry }\end{array}$ & $\begin{array}{l}\text { Developing } \\
\text { specialized } \\
\text { services for } \\
\text { ethnic } \\
\text { minorities, } \\
\text { refugees, and } \\
\text { asylum seekers }\end{array}$ & $\begin{array}{l}\text { This study has } \\
\text { given evidence } \\
\text { that, without losing } \\
\text { its usefulness for } \\
\text { the sake of valid } \\
\text { diagnosis, the BCI } \\
\text { (Brief Cultural } \\
\text { Interview) is more } \\
\text { feasible than the } \\
\text { longer CFI } \\
\text { (Cultural } \\
\text { Formulation } \\
\text { Interview) }\end{array}$ & $\begin{array}{l}\text { The promising } \\
\text { results of these } \\
\text { pilot data could } \\
\text { offer an } \\
\text { encouraging } \\
\text { impulse for the } \\
\text { culturally } \\
\text { sensitive } \\
\text { treatment of } \\
\text { mental health } \\
\text { problems, though } \\
\text { it requires } \\
\text { confirmation from } \\
\text { other studies } \\
\text { around the globe }\end{array}$ \\
\hline (55) & 2012 & USA & $\begin{array}{l}\text { This article } \\
\text { presents a pilot } \\
\text { program, the } \\
\text { "Psycho-Social- } \\
\text { Cultural Treatment } \\
\text { Group" for } \\
\text { Cambodian } \\
\text { refugees }\end{array}$ & $\begin{array}{l}\text { Making } \\
\text { innovations in } \\
\text { the therapeutic } \\
\text { framework of } \\
\text { general mental } \\
\text { health services: } \\
\text { Psycho-Social- } \\
\text { Cultural } \\
\text { Treatment } \\
\text { Group }\end{array}$ & $\begin{array}{l}\text { This program was } \\
\text { developed by } \\
\text { combining } \\
\text { Cambodian cultural } \\
\text { traditions and } \\
\text { spiritual } \\
\text { philosophy with } \\
\text { Western mental } \\
\text { health techniques }\end{array}$ & $\begin{array}{l}\text { It is suggested } \\
\text { that the current } \\
\text { pilot programs } \\
\text { might contribute } \\
\text { to helping } \\
\text { professions in } \\
\text { community-based } \\
\text { agencies that } \\
\text { work with } \\
\text { traumatized } \\
\text { Cambodians }\end{array}$ \\
\hline$(64)$ & 2003 & Canada & $\begin{array}{l}\text { This paper reports } \\
\text { results from the } \\
\text { evaluation of a } \\
\text { cultural } \\
\text { consultation } \\
\text { service (CCS) for } \\
\text { mental health } \\
\text { clinicians }\end{array}$ & $\begin{array}{l}\text { Cultural } \\
\text { consultation } \\
\text { services }\end{array}$ & $\begin{array}{l}\text { Cases seen by the } \\
\text { CCS clearly } \\
\text { demonstrated the } \\
\text { impact of cultural } \\
\text { misunderstandings. } \\
\text { Clinicians referring } \\
\text { patients to the } \\
\text { service reported } \\
\text { high rates of } \\
\text { satisfaction with } \\
\text { the consultations }\end{array}$ & $\begin{array}{l}\text { The cultural } \\
\text { consultation } \\
\text { model effectively } \\
\text { supplements } \\
\text { existing services } \\
\text { to improve } \\
\text { diagnostic } \\
\text { assessment and } \\
\text { treatment for a } \\
\text { culturally diverse } \\
\text { urban population. } \\
\text { Clinicians need } \\
\text { training in } \\
\text { working with } \\
\text { interpreters and } \\
\text { culture brokers. }\end{array}$ \\
\hline (16) & 2013 & Australia & This paper & i) Cultural & Participants from a & This pilot study \\
\hline
\end{tabular}




\begin{tabular}{|c|c|c|c|c|c|c|}
\hline & & & $\begin{array}{l}\text { describes the } \\
\text { development of a } \\
\text { pilot secondary } \\
\text { consultation } \\
\text { program by a } \\
\text { state-wide } \\
\text { transcultural } \\
\text { psychiatry unit }\end{array}$ & $\begin{array}{l}\text { competence } \\
\text { training for } \\
\text { professionals } \\
\text { and ii) Cultural } \\
\text { consultation } \\
\text { services }\end{array}$ & $\begin{array}{l}\text { range of disciplines } \\
\text { provided } \\
\text { consistently } \\
\text { positive feedback. } \\
\text { The sessions } \\
\text { provided an } \\
\text { effective forum for } \\
\text { discussing cultural } \\
\text { formulations and } \\
\text { culturally sensitive } \\
\text { approaches }\end{array}$ & $\begin{array}{l}\text { facilitated the } \\
\text { development of } \\
\text { cultural } \\
\text { consultation } \\
\text { services }\end{array}$ \\
\hline (49) & 2005 & Canada & $\begin{array}{l}\text { To look at the } \\
\text { specificities of the } \\
\text { work of a } \\
\text { Transcultural } \\
\text { Child Psychiatry } \\
\text { Team developed in } \\
\text { Montreal }\end{array}$ & $\begin{array}{l}\text { Making } \\
\text { innovations in } \\
\text { the therapeutic } \\
\text { framework of } \\
\text { general mental } \\
\text { health services: } \\
\text { Transcultural } \\
\text { Psychiatry Team }\end{array}$ & $\begin{array}{l}\text { The authors } \\
\text { explain the clinic's } \\
\text { development and } \\
\text { method of service } \\
\text { provision for its } \\
\text { patient population. } \\
\text { They also describe } \\
\text { the Transcultural } \\
\text { Child Psychiatry } \\
\text { Team and its } \\
\text { modalities of } \\
\text { assessment and } \\
\text { treatment }\end{array}$ & $\begin{array}{l}\text { In this model of } \\
\text { service delivery, } \\
\text { current mental } \\
\text { health care } \\
\text { practice is } \\
\text { modified in order } \\
\text { to address the } \\
\text { social specificities } \\
\text { and cultural } \\
\text { diversity of } \\
\text { transcultural } \\
\text { child psychiatric } \\
\text { populations }\end{array}$ \\
\hline (29) & 2009 & Canada & $\begin{array}{l}\text { This article } \\
\text { describes a } \\
\text { preliminary } \\
\text { qualitative } \\
\text { evaluation of a } \\
\text { mental health } \\
\text { program } \\
\text { in a multi-ethnic } \\
\text { environment in } \\
\text { Montréal }\end{array}$ & $\begin{array}{l}\text { Making } \\
\text { innovations in } \\
\text { the therapeutic } \\
\text { framework of } \\
\text { general mental } \\
\text { health services }\end{array}$ & $\begin{array}{l}\text { A preliminary } \\
\text { qualitative } \\
\text { evaluation of the } \\
\text { project showed the } \\
\text { numerous sources } \\
\text { of uncertainty } \\
\text { which participants } \\
\text { face }\end{array}$ & $\begin{array}{l}\text { The authors } \\
\text { formulate the } \\
\text { hypothesis that } \\
\text { uncertainties, } \\
\text { although they } \\
\text { generate } \\
\text { uneasiness and } \\
\text { confusion, also } \\
\text { enable an opening } \\
\text { toward innovation } \\
\text { and otherness }\end{array}$ \\
\hline (27) & 2006 & Canada & $\begin{array}{l}\text { This article } \\
\text { examines how the } \\
\text { issue of clinical } \\
\text { intervention with } \\
\text { the Aboriginals } \\
\text { presents itself } \\
\text { within Montreal's } \\
\text { transcultural } \\
\text { psychiatric } \\
\text { services }\end{array}$ & $\begin{array}{l}\text { Making } \\
\text { innovations in } \\
\text { the therapeutic } \\
\text { framework of } \\
\text { general mental } \\
\text { health services: } \\
\text { Transcultural } \\
\text { Psychiatry Team }\end{array}$ & $\begin{array}{l}\text { The author } \\
\text { questions the place } \\
\text { and response given } \\
\text { to the demands of a } \\
\text { minority unlike the } \\
\text { others, the } \\
\text { Aboriginals }\end{array}$ & $\begin{array}{l}\text { The creation of } \\
\text { transcultural } \\
\text { clinics is a } \\
\text { recognition by } \\
\text { public health } \\
\text { departments of } \\
\text { the importance of } \\
\text { the specificity of } \\
\text { the social } \\
\text { contexts, value } \\
\text { systems, and } \\
\text { interpretations of } \\
\text { reality of diverse } \\
\text { cultural groups }\end{array}$ \\
\hline (53) & 2013 & UK & This article & Cultural & Results indicate & They conclude \\
\hline
\end{tabular}




\begin{tabular}{|c|c|c|c|c|c|c|}
\hline & & & $\begin{array}{l}\text { presents the } \\
\text { preliminary results } \\
\text { of the } \\
\text { implementation of } \\
\text { a cultural } \\
\text { consultation } \\
\text { service (CCS) }\end{array}$ & $\begin{array}{l}\text { competence } \\
\text { training for } \\
\text { professionals }\end{array}$ & $\begin{array}{l}\text { that clinicians } \\
\text { developed a } \\
\text { broader and } \\
\text { patient-centered } \\
\text { understanding of } \\
\text { culture, and gained } \\
\text { skills in narrative- } \\
\text { based assessment } \\
\text { method, } \\
\text { management of } \\
\text { complexity of care, } \\
\text { and clinical } \\
\text { cultural } \\
\text { formulation }\end{array}$ & $\begin{array}{l}\text { that cultural } \\
\text { consultation } \\
\text { model is an } \\
\text { innovative way of } \\
\text { training clinicians } \\
\text { in cultural } \\
\text { competence skills }\end{array}$ \\
\hline (33) & 1990 & Australia & $\begin{array}{l}\text { It describes the } \\
\text { development of a } \\
\text { Service for the } \\
\text { treatment and } \\
\text { rehabilitation of } \\
\text { torture and trauma } \\
\text { survivors } \\
\text { (STARTTS) }\end{array}$ & $\begin{array}{l}\text { Developing } \\
\text { specialized } \\
\text { services }\end{array}$ & $\begin{array}{l}\text { The experience of } \\
\text { staff and responses } \\
\text { of survivors to } \\
\text { therapy have } \\
\text { illuminated a } \\
\text { number of issues } \\
\text { that are central to } \\
\text { the delivery of an } \\
\text { effective and } \\
\text { accessible service } \\
\text { of this kind }\end{array}$ & $\begin{array}{l}\text { Recognition of the } \\
\text { importance of } \\
\text { professional } \\
\text { training and } \\
\text { clinical expertise } \\
\text { in working with } \\
\text { disturbed } \\
\text { survivors of } \\
\text { torture and } \\
\text { trauma }\end{array}$ \\
\hline (21) & 2007 & Spain & $\begin{array}{l}\text { The aim of this } \\
\text { preliminary } \\
\text { research was to } \\
\text { create several } \\
\text { forms appropriate } \\
\text { to a specific model } \\
\text { of medical } \\
\text { attention for the } \\
\text { mental health for } \\
\text { people culturally } \\
\text { different and/or at } \\
\text { risk of social } \\
\text { marginalization }\end{array}$ & $\begin{array}{l}\text { i) Cultural } \\
\text { competence } \\
\text { training for } \\
\text { professionals } \\
\text { and ii) } \\
\text { Supervision and } \\
\text { consultation } \\
\text { services }\end{array}$ & $\begin{array}{l}\text { This model defends } \\
\text { and tries to put } \\
\text { into practice a sort } \\
\text { of assistance in } \\
\text { which special } \\
\text { attention is paid to } \\
\text { every cultural, } \\
\text { social, political or } \\
\text { economic variable } \\
\text { that can be related } \\
\text { to people's mental } \\
\text { health }\end{array}$ & $\begin{array}{l}\text { The } \\
\text { representations of } \\
\text { health and } \\
\text { disease determine } \\
\text { in a very } \\
\text { significant way } \\
\text { both the Medical } \\
\text { Care Process and } \\
\text { the population's } \\
\text { levels of health }\end{array}$ \\
\hline (19) & 2017 & Australia & $\begin{array}{l}\text { This article } \\
\text { describes the } \\
\text { expansion of a } \\
\text { transcultural } \\
\text { secondary } \\
\text { consultation model } \\
\text { run by a state-wide } \\
\text { transcultural unit }\end{array}$ & $\begin{array}{l}\text { Cultural } \\
\text { consultation } \\
\text { services }\end{array}$ & $\begin{array}{l}\text { The results } \\
\text { emphasize the need } \\
\text { for } \\
\text { multidisciplinary } \\
\text { collaboration and a } \\
\text { facilitated space for } \\
\text { clinical teams to } \\
\text { explore culturally } \\
\text { responsive } \\
\text { therapeutic } \\
\text { practices }\end{array}$ & $\begin{array}{l}\text { The discussion } \\
\text { highlights the } \\
\text { usefulness of a } \\
\text { transcultural } \\
\text { model of } \\
\text { consultation and } \\
\text { identifies the } \\
\text { benefits the model } \\
\text { brings to } \\
\text { understanding } \\
\text { and intervening } \\
\text { with clients, }\end{array}$ \\
\hline
\end{tabular}




\begin{tabular}{|c|c|c|c|c|c|c|}
\hline & & & & & & $\begin{array}{l}\text { culture, and } \\
\text { systems }\end{array}$ \\
\hline (9) & 2017 & Belgium & $\begin{array}{l}\text { This article } \\
\text { proposes an } \\
\text { intervention } \\
\text { methodology that } \\
\text { improves access to } \\
\text { and the } \\
\text { effectiveness of } \\
\text { mental health care } \\
\text { facilities for } \\
\text { children and their } \\
\text { families with } \\
\text { backgrounds as } \\
\text { refugees and } \\
\text { migrants }\end{array}$ & $\begin{array}{l}\text { Support of a } \\
\text { non-profit } \\
\text { organization, } \\
\text { specialized in } \\
\text { refugee care, } \\
\text { embedded in a } \\
\text { psychiatric unit }\end{array}$ & $\begin{array}{l}\text { This intervention } \\
\text { has a positive } \\
\text { influence on } \\
\text { creating healing } \\
\text { ties between } \\
\text { parents and care } \\
\text { providers }\end{array}$ & $\begin{array}{l}\text { There is a need } \\
\text { for further } \\
\text { research on the } \\
\text { effectiveness of } \\
\text { transcultural } \\
\text { interventions, } \\
\text { which would allow } \\
\text { for a more } \\
\text { structural } \\
\text { implementation of } \\
\text { them }\end{array}$ \\
\hline (23) & 2011 & USA & $\begin{array}{l}\text { The aim of this } \\
\text { study was to } \\
\text { identify } \\
\text { components of } \\
\text { cultural } \\
\text { competence in } \\
\text { mental health } \\
\text { programs } \\
\text { developed for } \\
\text { cultural groups by } \\
\text { community and } \\
\text { mental health } \\
\text { professionals from } \\
\text { these groups }\end{array}$ & $\begin{array}{l}\text { i) Cultural } \\
\text { competence } \\
\text { training for } \\
\text { professionals } \\
\text { and ii) Making } \\
\text { innovations in } \\
\text { the therapeutic } \\
\text { framework of } \\
\text { general mental } \\
\text { health services: } \\
\text { Family and } \\
\text { community } \\
\text { involvement }\end{array}$ & $\begin{array}{l}\text { Components } \\
\text { included } \\
\text { communication } \\
\text { competencies; staff } \\
\text { in culturally } \\
\text { acceptable roles; } \\
\text { culturally framed } \\
\text { trust building, } \\
\text { stigma reduction, } \\
\text { friendly milieus } \\
\text { and services; and } \\
\text { peer, family, and } \\
\text { community } \\
\text { involvement }\end{array}$ & $\begin{array}{l}\text { Incorporating } \\
\text { these components } \\
\text { into any program } \\
\text { in which } \\
\text { underserved } \\
\text { cultural } \\
\text { populations are } \\
\text { seen is } \\
\text { recommended for } \\
\text { improving } \\
\text { cultural } \\
\text { competence }\end{array}$ \\
\hline (34) & 2015 & Australia & $\begin{array}{l}\text { This paper } \\
\text { describes the } \\
\text { STARTTerS Early } \\
\text { Childhood program } \\
\text { (Service for the } \\
\text { Treatment and } \\
\text { Rehabilitation of } \\
\text { Torture and } \\
\text { Trauma Survivors) }\end{array}$ & $\begin{array}{l}\text { Making } \\
\text { innovations in } \\
\text { the therapeutic } \\
\text { framework of } \\
\text { general mental } \\
\text { health services: } \\
\text { A model for } \\
\text { collaborative } \\
\text { and consultative } \\
\text { design and } \\
\text { implementation } \\
\text { of culturally } \\
\text { appropriate } \\
\text { services }\end{array}$ & $\begin{array}{l}\text { This research has } \\
\text { led to ongoing } \\
\text { collaborative and } \\
\text { consultative } \\
\text { processes, } \\
\text { resulting in the } \\
\text { development of } \\
\text { services and } \\
\text { referral systems, } \\
\text { which will build a } \\
\text { comprehensive and } \\
\text { culturally } \\
\text { appropriate early } \\
\text { childhood program }\end{array}$ & $\begin{array}{l}\text { Systemic } \\
\text { programs as } \\
\text { community } \\
\text { consultation, } \\
\text { research, cross- } \\
\text { referral and } \\
\text { liaison with other } \\
\text { service providers } \\
\text { can be used to } \\
\text { provide } \\
\text { appropriate } \\
\text { mental health } \\
\text { care }\end{array}$ \\
\hline (26) & 2006 & Canada & $\begin{array}{l}\text { It describes the } \\
\text { development of the } \\
\text { transcultural } \\
\text { project of Jean- } \\
\text { Talon Hospital } \\
\text { (Montréal) }\end{array}$ & $\begin{array}{l}\text { Making } \\
\text { innovations in } \\
\text { the therapeutic } \\
\text { framework of } \\
\text { general mental } \\
\text { health services }\end{array}$ & $\begin{array}{l}\text { It provides an } \\
\text { historic } \\
\text { perspective of the } \\
\text { transcultural } \\
\text { approach and the } \\
\text { context of Jean- }\end{array}$ & $\begin{array}{l}\text { The author gives } \\
\text { some ideas on } \\
\text { how Québec could } \\
\text { contribute to the } \\
\text { future }\end{array}$ \\
\hline
\end{tabular}




\begin{tabular}{|c|c|c|c|c|c|c|}
\hline & & & & & $\begin{array}{l}\text { Talon project } \\
\text { development }\end{array}$ & $\begin{array}{l}\text { development of } \\
\text { ethnopsychiatry }\end{array}$ \\
\hline (15) & 2011 & Italy & $\begin{array}{l}\text { It aims to evaluate } \\
\text { the effectiveness of } \\
\text { "Bologna West } \\
\text { Transcultural } \\
\text { Psychiatric Team" } \\
\text { and to describe the } \\
\text { characteristics of } \\
\text { patient and } \\
\text { psychiatric } \\
\text { interventions } \\
\text { related to } \\
\text { dropping out. }\end{array}$ & $\begin{array}{l}\text { Consultation } \\
\text { liaison activities } \\
\text { to improve } \\
\text { cultural } \\
\text { competence }\end{array}$ & $\begin{array}{l}\text { The strongest } \\
\text { predictors of } \\
\text { dropping out were } \\
\text { non-Asian origin, a } \\
\text { recent history of } \\
\text { migration, and not } \\
\text { receiving social } \\
\text { intervention. }\end{array}$ & $\begin{array}{l}\text { Psychiatric } \\
\text { consultation } \\
\text { services to } \\
\text { migrants could be } \\
\text { made more } \\
\text { effective by } \\
\text { enhancing: (a) } \\
\text { cultural } \\
\text { competence, } \\
\text { through cultural } \\
\text { mediator } \\
\text { involvement; and } \\
\text { (b) social support } \\
\text { from the first } \\
\text { psychiatric } \\
\text { contact }\end{array}$ \\
\hline (7) & 2009 & Italy & $\begin{array}{l}\text { The aim of this } \\
\text { study was to } \\
\text { investigate the } \\
\text { socio-demographic } \\
\text { and clinical } \\
\text { features of } \\
\text { immigrants } \\
\text { referred to the } \\
\text { Bologna-West } \\
\text { Transcultural } \\
\text { Psychiatric Team }\end{array}$ & $\begin{array}{l}\text { Consultation } \\
\text { liaison activities } \\
\text { to improve } \\
\text { cultural } \\
\text { competence }\end{array}$ & $\begin{array}{l}\text { Clinical diagnoses, } \\
\text { psychopathology } \\
\text { and pathways to } \\
\text { care were closely } \\
\text { related to socio- } \\
\text { demographic } \\
\text { features and ethnic } \\
\text { group }\end{array}$ & $\begin{array}{l}\text { More efforts } \\
\text { should be made to } \\
\text { ameliorate } \\
\text { pathways to care } \\
\text { among migrants }\end{array}$ \\
\hline (22) & 2005 & USA & $\begin{array}{l}\text { Qualitative } \\
\text { assessment of } \\
\text { cross-cultural } \\
\text { mental health } \\
\text { services in } \\
\text { California }\end{array}$ & $\begin{array}{l}\text { i) Ethnic } \\
\text { matching and ii) } \\
\text { Cultural } \\
\text { competence } \\
\text { training for } \\
\text { professionals }\end{array}$ & $\begin{array}{l}\text { Ethnic matching } \\
\text { (whereby the } \\
\text { ethnicity of the } \\
\text { patient is matched } \\
\text { with the ethnicity } \\
\text { of the clinician) } \\
\text { and cultural- } \\
\text { competency } \\
\text { training emerged } \\
\text { as prevalent } \\
\text { strategies to } \\
\text { address patient } \\
\text { diversity. }\end{array}$ & $\begin{array}{l}\text { Strategies } \\
\text { commonly used to } \\
\text { improve culturally } \\
\text { appropriate } \\
\text { mental health } \\
\text { care are often } \\
\text { inadequate to } \\
\text { meet the needs of } \\
\text { diverse } \\
\text { communities. New } \\
\text { strategies such as } \\
\text { a Cultural } \\
\text { Consultation } \\
\text { Service are } \\
\text { needed to } \\
\text { supplement } \\
\text { existing services }\end{array}$ \\
\hline
\end{tabular}

Table 4-Characteristics of the included papers 
Page $27 / 31$ 


\begin{tabular}{|c|c|c|c|c|}
\hline & Country & Types of services & Description & Cited in \\
\hline \multirow[t]{3}{*}{$\begin{array}{l}\text { Substantial } \\
\text { immigration } \\
\text { from former } \\
\text { colonies }\end{array}$} & \multirow[t]{3}{*}{ UK } & $\begin{array}{l}\text { Services for minority } \\
\text { ethnic communities }\end{array}$ & $\begin{array}{l}\text { Transcultural Psychiatry Unit at Bradford, } \\
\text { the Maudsley Outreach Support and } \\
\text { Treatment Team, the North Birmingham } \\
\text { Home Treatment Service, the volunteer } \\
\text { organization "Ipamo" }\end{array}$ & $(12)$ \\
\hline & & $\begin{array}{l}\text { Cultural Consultation } \\
\text { Service }\end{array}$ & $\begin{array}{l}\text { The CCS is an innovative model to promote } \\
\text { cultural competence of clinicians and } \\
\text { directly improve patient experiences and } \\
\text { outcomes from care }\end{array}$ & $(52,53)$ \\
\hline & & $\begin{array}{l}\text { Transcultural Mental } \\
\text { Health worker }\end{array}$ & $\begin{array}{l}\text { Use of transcultural mental health workers } \\
\text { as an alternative to interpreters in an } \\
\text { attempt to identify the communication } \\
\text { barriers and improve the mental health } \\
\text { care for black \& minority ethnic patients }\end{array}$ & $(54)$ \\
\hline \multirow{8}{*}{$\begin{array}{l}\text { Multicultural } \\
\text { citizenship } \\
\text { model } \\
\text { countries }\end{array}$} & \multirow[t]{3}{*}{ USA } & $\begin{array}{l}\text { Mental Healthcare for } \\
\text { minority ethnic } \\
\text { communities }\end{array}$ & $\begin{array}{l}\text { Mental Health clinics for ethnic minorities } \\
\text { or ethnic matching between clinician and } \\
\text { patient }\end{array}$ & $(22)$ \\
\hline & & $\begin{array}{l}\text { Psycho-Social-Cultural } \\
\text { Treatment Group }\end{array}$ & $\begin{array}{l}\text { Specialized program for refugees, } \\
\text { combining their cultural traditions and } \\
\text { Buddhist philosophy with Western mental } \\
\text { health techniques }\end{array}$ & (55) \\
\hline & & Cultural Competence & $\begin{array}{l}\text { National Center for Cultural Competence: } \\
\text { to design, implement, and evaluate } \\
\text { culturally and linguistically competent } \\
\text { service delivery systems to address } \\
\text { growing diversity, persistent disparities, } \\
\text { and to promote health and mental health } \\
\text { equity }\end{array}$ & $(23,40)$ \\
\hline & \multirow[t]{4}{*}{ Canada } & $\begin{array}{l}\text { Transcultural Psychiatric } \\
\text { Teams }\end{array}$ & $\begin{array}{l}\text { Transcultural Psychiatric Teams of Jean- } \\
\text { Talon Hospital; Montreal Children Hospital }\end{array}$ & $(26,27,49)$ \\
\hline & & $\begin{array}{l}\text { Projet de soins concertés } \\
\text { en santé mentale jeunesse } \\
\text { dans un milieu } \\
\text { pluriethnique (joint care } \\
\text { project for youth mental } \\
\text { health in a multiethnic } \\
\text { environment) }\end{array}$ & $\begin{array}{l}\text { Partnership between the transcultural } \\
\text { psychiatry team at Montreal Children's } \\
\text { Hospital and professionals at local } \\
\text { community centers (CLSC) and youth } \\
\text { centers }\end{array}$ & (29) \\
\hline & & $\begin{array}{l}\text { Cross Cultural Mental } \\
\text { Health Services }\end{array}$ & $\begin{array}{l}\text { A culturally responsible approach to } \\
\text { diagnosis and treatment. Clients' cultural } \\
\text { and language needs are matched with a } \\
\text { staff member who can speak the language } \\
\text { and/or is familiar with the culture. }\end{array}$ & (13) \\
\hline & & Cultural Consultation & $\begin{array}{l}\text { Various forms of cultural consultation, } \\
\text { including direct assessment, secondary } \\
\text { consultation and discussions with } \\
\text { community organizations about cross- } \\
\text { cultural aspects of mental health }\end{array}$ & $(64)$ \\
\hline & Australia & $\begin{array}{l}\text { Transcultural Consultation } \\
\text { Program }\end{array}$ & $\begin{array}{l}\text { It assists mental health services through } \\
\text { workforce training and service }\end{array}$ & $(16,19)$ \\
\hline
\end{tabular}




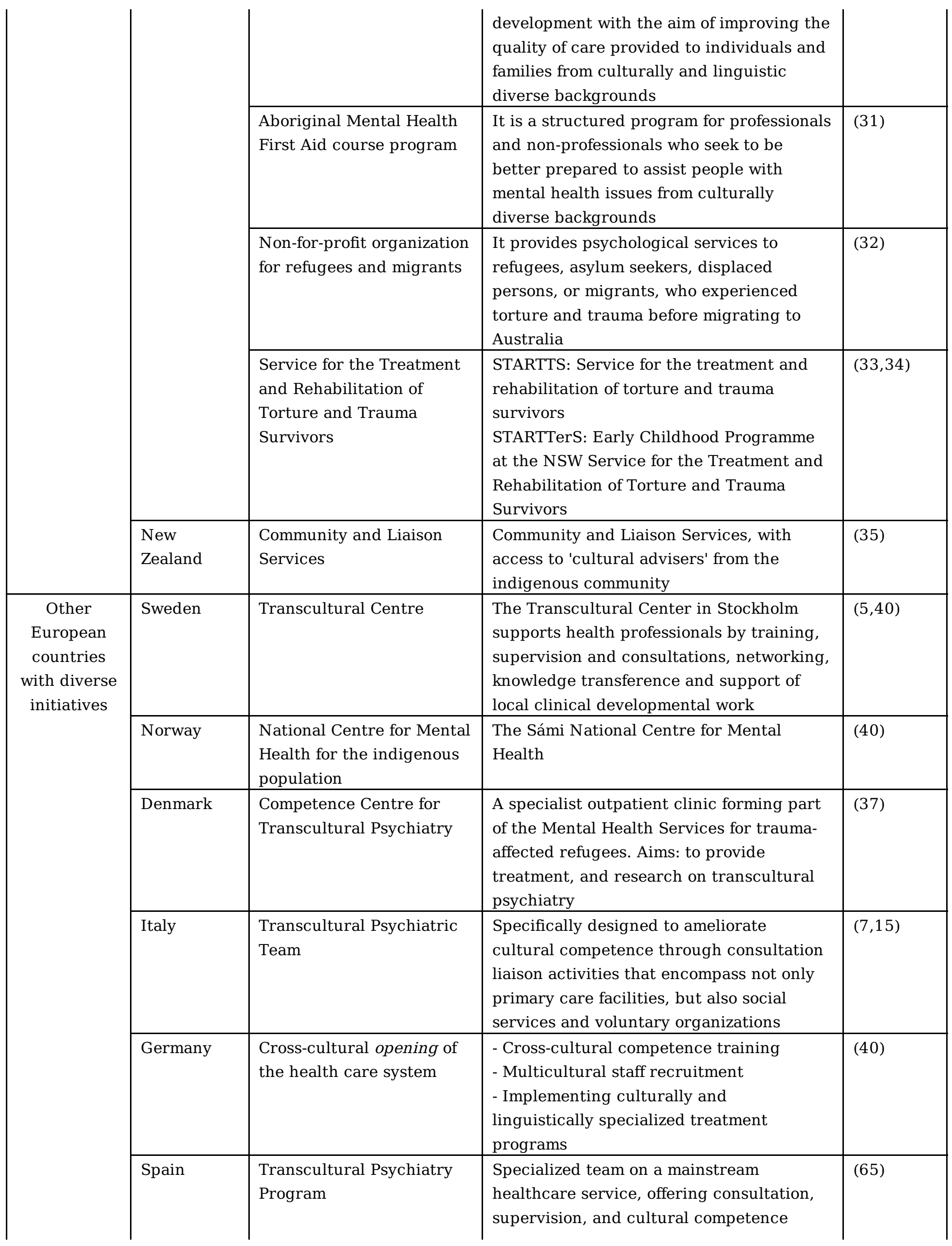




\begin{tabular}{|c|c|c|c|}
\hline & & $\begin{array}{l}\text { training for professionals; mental health } \\
\text { care for migrants }\end{array}$ & \\
\hline Netherlands & $\begin{array}{l}\text { - Interculturalization of } \\
\text { mental health services } \\
\text { - Centre for Transcultural } \\
\text { Psychiatry }\end{array}$ & $\begin{array}{l}\text { De Evenaar is a Center for Transcultural } \\
\text { Psychiatry that provides mental health } \\
\text { care in the northern part of the } \\
\text { Netherlands to migrants, refugees, and } \\
\text { asylum seekers. The Center offers several } \\
\text { adult and youth therapy programs, both } \\
\text { inpatient or outpatient care }\end{array}$ & $(38,63)$ \\
\hline Belgium & $\begin{array}{l}\text { Psychiatry Assisting a } \\
\text { Cultural diverse } \\
\text { Community in creating } \\
\text { healing Ties (PACCT) }\end{array}$ & $\begin{array}{l}\text { Non-profit organization that provides } \\
\text { mental health care for children and their } \\
\text { families with a refugee and migration } \\
\text { background }\end{array}$ & (9) \\
\hline
\end{tabular}

\section{Table 5 - Description of international transcultural services}

\section{Figures}




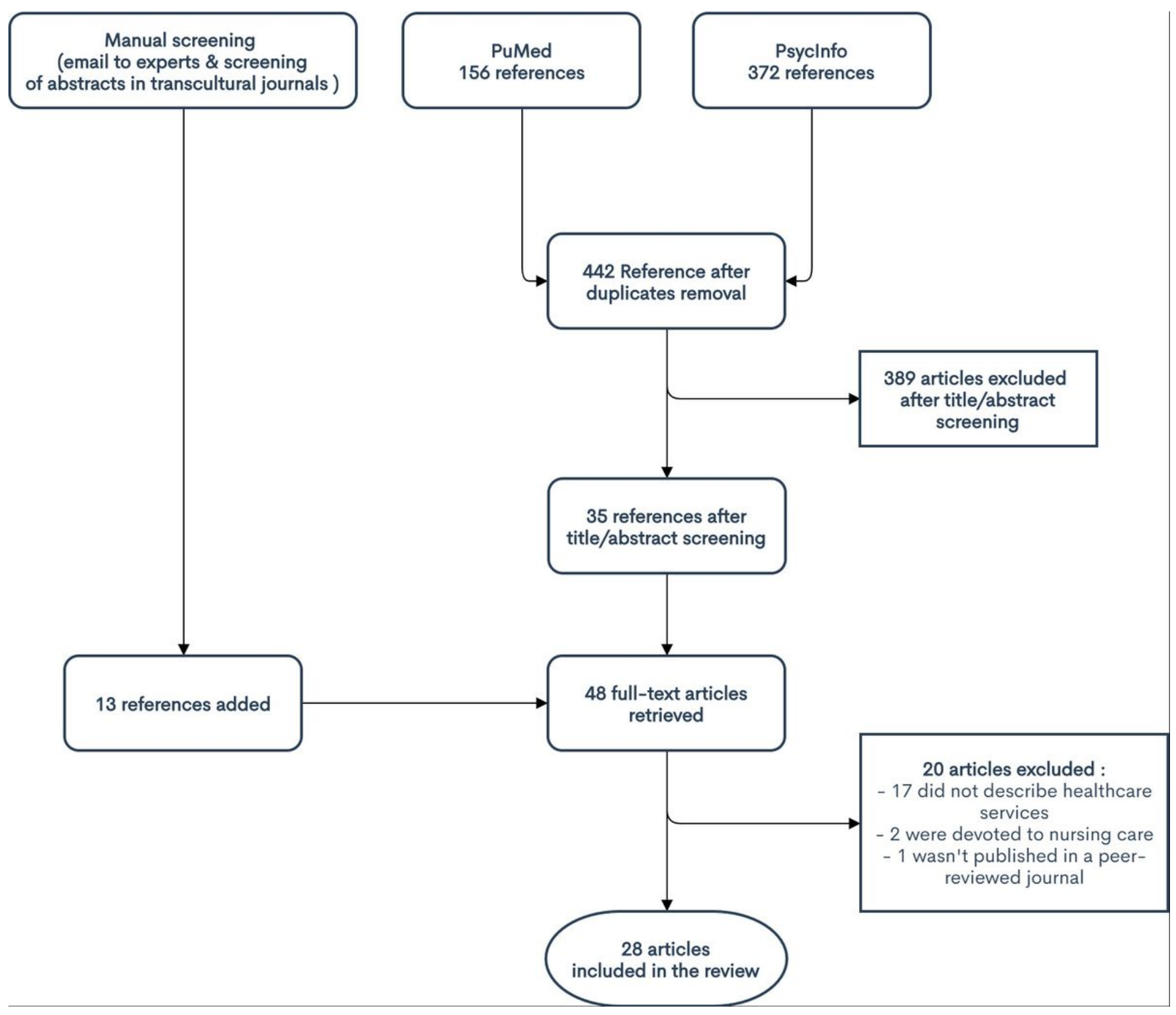

Figure 1

Flowchart of the studies included

\section{Supplementary Files}

This is a list of supplementary files associated with this preprint. Click to download.

- PRISMAScRFillableChecklist.docx 